\title{
The impact of the Devaluation of the Surinamese Dollar (2015 - 2016) on Food Intake in Suriname
}

\author{
Cheuk-A-Lam Gerani ${ }^{1 *}$, D'Haese Marijke ${ }^{1}$, Van Camp John ${ }^{1}$ \\ ${ }^{l}$ Ghent University, Faculty of Bioscience Engineering, Coupure Links 653, 9000 Gent, Belgium
}

Corresponding Author: Cheuk - A - Lam Gerani, Ghent University, Faculty of Bioscience Engineering, Coupure Links 653, 9000 Gent, Belgium

Received date: July 27, 2019; Accepted date: October 16, 2019; Published date: October 18, 2019

DOI: https://doi.org/10.31546/IJFSNR.1006

\section{Abstract}

Objective: A currency devaluation influences food prices and populations' diet, especially in developing countries and within poorer households, resulting in the consumption of cheaper, and therefore often lower quality diets. Reduced consumption of high-quality foods restrains the protective health benefits of these foods towards the incidence of NCDs, and increases the risk of micro- and macronutrient deficiencies among populations that are already subject to food and nutrition insecurity. Despite global evidence of higher food prices directly affecting populations' health status, and as such possibly jeopardizing economic performance and rural development, there has been no research conducted on the effect of rising food prices on food intake in Suriname yet. As such, the objective of this study was to assemble primary food consumption data, with respect to pre-and post-devaluation food intake patterns of Surinamese households. This with the goal to report changes in post-devaluation dietary intake, in order to better comprehend the future implications for health, facilitating evidence-based policy development and nutrition intervention planning.

Results: Higher food prices resulted in low, - middle - and high-income groups increasing the expenditures on food ( $p<0.01)$. Reductions in the proportion of households' significantly lowering the post-devaluation intake of high-quality foods, such as fruits, vegetables, lean meat and fatty fish were observed $(\mathrm{p}<0.01)$. Furthermore, changes in the intake of low-quality foods were witnessed as well, with proportions of households significantly reducing the intake of discretionary foods and terminating eating out-of-home ( $p$ $<0.01)$.

Conclusion: The fall of the Surinamese currency, in combination with country's dependency on imported foods, increased local food prices and with salaries remaining the same, resulted in both lower- and higherincome households increasing their food expenditures. Post-devaluation changes in regular dietary pattern and food intake enrolled, with a significant reduction in the consumption of high-quality foods being noticed, especially within lower-economic households. On the one hand, significant proportions of Surinamese households possess a decreased probability of consuming healthy diets. On the other hand, households with also a significant reduction in the intake of low-quality foods might encounter a beneficial health impact if already coping with overweight and related non-communicable diseases.

Keywords: Devaluation, Food price rises, nutrition, Food consumption, Low and Middle-income countries. 


\section{Introduction}

Devaluation involves a fall in the value of a country's currency within a fixed exchange rate system and therefore increases inflation. Starting November 2015, the Surinamese currency devalued with more than $50 \%$ as a result of the rapid decrease in monetary reserves, due to an imbalance between governments' revenues and expenditures. Apart from the global economic and financial crisis engulfing the developing world, the economic crisis in Suriname induced even higher local food and fuel prices. Bodies of evidence have shown that in times of crisis, households adopt coping strategies which are likely to cause significant changes in diets and nutrient intake with direct and indirect implications for health and economic development [48]. Some of these strategies are cutting expenditures on food, reducing overall food intake by skipping meals, reducing portion sizes and shifting the type of foods consumed. Overall, consumers switch from costly, high-quality to cheaper, lowquality diets. The latter often consisting of high-calorie but lownutrient foods. As such, the devaluation of a country's currency can execute an increased burden on the budgets of especially groups of limited economic means, reducing their purchasing power and forcing them to adopt less costly, yet high-energydense diets [7,10,18,22,25,27,28,33,45]. When nutritional needs are not met, people might fall into a state of malnutrition, hence becoming prone to illness and having lower productivity levels.

The objective of the study was to assemble primary data on preand post-devaluation food intake in Paramaribo, in order to determine whether there was a significant difference between consumers' pre-and post-devaluation food consumption. As such, changes in diet frequency, portion size and food quality were measured. Of particular interest were changes in starchy carbohydrates (e.g. rice and potatoes), dairy products, fruits, vegetables, meat, fish, eggs and discretionary foods. The goal was to report and evaluate the most significant changes in food intake and the possible consequences for public health and economic development in Paramaribo. As such, this study made the link between food prices and dietary intake stating the impact of the Surinamese currency devaluation on long-term implications for health.

\section{Materials and Methods \\ Dietary Intake Assessment}

In this study, a version of the Healthy Eating Index questionnaire adapted to the Surinamese diet; supported by recommendations of the Belgian Food Guidelines was used, involving 201 participants and covering 10 main food groups. Moreover, information on anthropometric measurements, sociodemographics, health status and dietary habits and frequencies were gathered [13].
A team of six interviewers received a 2-hour training on how to complete the FFQ during their visit to the respondents. The training involved an explanation on recruitment strategies, clarification of survey content, serving size photos for reference and online examples of each product group considered. Food categories included bread, rice and potatoes in the category of starchy carbohydrates, dairy products, fruits, vegetables, meat, fish, eggs, junk food and sugarsweetened beverages etc [40]. Moreover, portion pictures, measurement examples and examples of specific Surinamese foods were included. The preparation method, mixed dishes, brand name and nutritional composition of the foods were not mentioned as this research merely focused on whether there is a change in frequency and portion size of the food groups consumed. Participants reported changes in dietary frequency, portion size and quality of a wide range of high- and low-quality foods pre and post the devaluation. Food products belonging to the lowquality diet were processed meat products, nonalcoholic sugar-sweetened beverages and discretionary foods such as baked goods, sweets and junk food. Those belonging to a high-quality diet were starchy carbohydrates, dairy, fruits, vegetables, meat, eggs and fish $[4,38,43]$.

\section{Survey Area and Sampling Procedure}

The survey took place in the capital of Suriname, Paramaribo, and included participants in the age range of 15 and 64. The population recruited for the study is representative of the population of Suriname as almost half of the Surinamese population $(\mathrm{N}=250.00)$ lives in Paramaribo. Therefore, sampling in this district increased the external validity of the field study making it possible to generalize to a large sample of participants [52]. Within the capital city, Paramaribo is divided into 11 main resorts. This demarcation corrects for confounding factors such as accessibility to healthy foods and food price differences between districts [53]. In each resort, we randomly selected three streets (with a minimum of five streets in between) by the use of resort maps. Interviewers randomly selected a household in each street from where they allocated their first sample. Afterwards, interviewers circumvented the following five houses, before selecting their next household. This procedure was repeated until the necessary amount of surveys was obtained $(\mathrm{N}=201)$ [12]. 
Respondents were orally and in writing introduced to the objective, stakeholders and the confidentiality of the study. If willing to participate, they signed the declaration of consent. After which respondents were interviewed on their sociodemographic factors, pre-and post-devaluation food expenditure and food $\&$ beverage intakes. Interviewers clearly communicated to report changes in food consumption, due to factors other than food price rises, as no change.

\section{Pre-Statistical Analyses}

Prior to conducting the analyses, an examination of assumption of normally distributed difference score took place. Visual inspection of the normal Q-Q plots and Boxplots showed that the changes in consumption were not normally distributed. Hence, to compare paired means for continuous, not normally distributed data, the nonparametric Wilcoxon Signed-Ranks Test was used $(\alpha=0.05$; CI: $95 \%)$ in order to determine whether there were changes in pre-and post-median frequency consumption and portion size of several food groups.

\section{Assessment of changes in food intake}

For the overview of the socio-demographic factors and the type of food products consumed, the survey results were processed in IBM SPSS Statistical Analyses, using "Descriptive Statistics; Crosstabs 'with the additional' Statistics'- command "Chi Square. The findings were treated as paired data since for each experimental unit (i.e. number of participants) there were two measurements, followed up before and after the start of the devaluation. As such, to test whether there was a postdevaluation difference in frequency consumption and portion size, the targeted food groups were each analyzed in IBM SPSS Statistics using the Wilcoxon Signed rank-test $(\alpha=0.05)$. The null hypothesis assuming equal medians was rejected in favor of the alternative, in case the sigma (2-tailed) value was smaller than alpha $(p<0.05=\alpha)$. Stating that for these food groups there was a significant difference in median consumption before and after the devaluation. The difference in food type is determined by descriptive statistics; Frequencies.

\section{Analyses on Socio-Demographic Effect}

To determine whether there was a significant difference between socio-demographic factors and changes in food intake between groups, the data was analyzed using Analyses of variance (One-way ANOVA $(\alpha=0.05))$. A multiple comparison of means (Tukey's Honest Significant Difference method $(\alpha=$ $0.05)$ ) is performed to assess where the significant difference between groups lies. In case the assumption of homogeneity of variances for multiple comparisons of means was violated (assessed by the Levene's test for Equality of Variances), the Kruskal Wallis-H test was used. This test analyzed the distribution of change in consumption between socio-economic determinants such as area

of residency (resort), household income and education level comparing the change in distribution by the use of mean ranks.

\section{Results \\ Changes in Income and Food Expenditure since the Devaluation}

More than half of the participants $(72 \%)$ reported no increase in salary since the onset of the devaluation. Only a small number of respondents (7\%) acquired a raise relatively close to the currency devaluation (i.e. between 20-40\%). Before the devaluation, less than 10 $\%$ of the population spent more than $50 \%$ of income on food, but at the moment of data collection that number increased to nearly $40 \%$. Not only low-income but also middle-and higher income households became vulnerable towards the higher food prices. However, the expenditures in lower income households increased to a greater extent $[15,24,32,36]$.

\section{Findings on changes in high-quality diets}

Table 1 presents significant pre- and post-devaluation consumption differences in food groups essentially belonging to a high-quality diet. The table looks at starchy carbohydrates, dairy, white meat (poultry) \& eggs, fruits, vegetables and fish [1].

Table 1: Comparative analyses of median reported pre- and post-devaluation food intake and consumer change concerning high-quality diets in Suriname, 2015-2016.

\begin{tabular}{|c|c|c|c|c|c|c|c|c|c|}
\hline \multirow{3}{*}{$\begin{array}{l}\text { Food } \\
\text { group }\end{array}$} & \multirow{3}{*}{$\begin{array}{l}\text { Reporting } \\
\text { unit }\end{array}$} & \multirow{3}{*}{$\begin{array}{l}\text { Sig } \\
\text { value } \\
(\mathbf{p})^{2}\end{array}$} & Min. & & \multirow{3}{*}{$\begin{array}{l}\text { Non - } \\
\text { consumers } \\
(\%)\end{array}$} & \multirow{2}{*}{\multicolumn{4}{|c|}{$\begin{array}{l}\text { Consumer change in food } \\
\text { intake since the } \\
\text { devaluation }\end{array}$}} \\
\hline & & & \multicolumn{2}{|c|}{$\begin{array}{l}\text { Max. } \\
\text { Median }\end{array}$} & & & & & \\
\hline & & & Before & After & & $\begin{array}{l}\text { Stopped } \\
(\%)\end{array}$ & $\begin{array}{l}\text { Lower } \\
(\%)\end{array}$ & $\begin{array}{l}\text { Same } \\
(\%)\end{array}$ & $\begin{array}{l}\text { Higher } \\
(\%)\end{array}$ \\
\hline
\end{tabular}


Cheuk -A -Lam Gerani et al.

\begin{tabular}{|c|c|c|c|c|c|c|c|c|c|}
\hline \multirow[t]{3}{*}{ Bread } & \multirow{3}{*}{$\begin{array}{l}\text { Quantity } \\
\text { of bread/ } \\
\text { serving } \\
\text { p/day }\end{array}$} & \multirow[t]{3}{*}{$<0.01$} & 1 & 1 & \multirow[t]{3}{*}{10} & \multirow[t]{3}{*}{-} & \multirow[t]{3}{*}{14} & \multirow[t]{3}{*}{85} & \multirow[t]{3}{*}{1} \\
\hline & & & 10 & 10 & & & & & \\
\hline & & & 2 & 2 & & & & & \\
\hline \multirow[t]{6}{*}{ Rice } & \multirow{3}{*}{$\begin{array}{l}\text { Portions } \\
\text { p/day }\end{array}$} & \multirow[t]{3}{*}{$<0.01$} & 0 & 0 & \multirow[t]{3}{*}{4} & \multirow[t]{3}{*}{-} & \multirow[t]{3}{*}{19} & \multirow[t]{3}{*}{80} & \multirow[t]{3}{*}{1} \\
\hline & & & 13 & 13 & & & & & \\
\hline & & & 2 & 1 & & & & & \\
\hline & \multirow{3}{*}{$\begin{array}{l}\text { Tbs. } \\
\text { p/portion }\end{array}$} & \multirow[t]{3}{*}{0.02} & 1 & 1 & \multirow[t]{3}{*}{4} & \multirow[t]{3}{*}{-} & \multirow[t]{3}{*}{11} & \multirow[t]{3}{*}{81} & 8 \\
\hline & & & 30 & 30 & & & & & \\
\hline & & & 6 & 6 & & & & & \\
\hline Boiled & Portions & $<0.01$ & 0 & 0 & 34 & - & 38 & 62 & - \\
\hline potatues & & & 8 & 7 & & & & & \\
\hline & & & 1 & 1 & & & & & \\
\hline & Quantity & $<0.01$ & 1 & 1 & 33 & - & 30 & 69 & 1 \\
\hline & p/portion & & 8 & 5 & & & & & \\
\hline & & & 2 & 2 & & & & & \\
\hline & & & 12 & 12 & & & & & \\
\hline & & & 1 & 1 & & & & & \\
\hline Dairy & & & & & & & & & \\
\hline Cheese & Days & $<0.01$ & 0 & 0 & 33 & - & 34 & 66 & - \\
\hline & & & 7 & 7 & & & & & \\
\hline & & & 3 & 2 & & & & & \\
\hline Milk & Glasses & $<0.01$ & 1 & 0 & 26 & - & 30 & 69 & 1 \\
\hline & $(250 \mathrm{ml})$ & & 16 & 9 & & & & & \\
\hline & p/day & & 2 & 1 & & & & & \\
\hline Yoghurt & Cups (250 & $<0.01$ & 0 & 0 & 56 & - & 32 & 67 & 1 \\
\hline & $m l)$ & & 7 & 5 & & & & & \\
\hline & p/day & & 1 & 1 & & & & & \\
\hline White mes & (Poultry) \& & ggs & & & & & & & \\
\hline Fresh & Days & $<0.01$ & 1 & 0 & 26 & - & 24 & 75 & 1 \\
\hline poultry & p/week & & 7 & 7 & & & & & \\
\hline & & & 4 & 3 & & & & & \\
\hline Frozen & Days & $<0.01$ & 0 & 0 & - & & 14 & 24 & 62 \\
\hline poultry & p/week & & 7 & 7 & & & & & \\
\hline & & & 3 & 6 & & & & & \\
\hline Chicken & Days & $<0.01$ & 0 & 0 & 54 & - & 20 & 78 & 2 \\
\hline breast & p/week & & 7 & 7 & & & & & \\
\hline filet & & & 2 & 1 & & & & & \\
\hline Serving & Pieces & $<0.01$ & 1 & 0 & 10 & - & 28 & 71 & 1 \\
\hline $\begin{array}{l}\text { size } \\
\text { chicken }\end{array}$ & p/portion & & $\frac{5}{2}$ & $\frac{5}{2}$ & & & & & \\
\hline Eggs & Days & $<0.01$ & $\frac{2}{0}$ & $\frac{2}{0}$ & 9 & - & 22 & 76 & 2 \\
\hline & p/week & & 7 & 7 & & & & & \\
\hline & & & 3 & 2 & & & & & \\
\hline Fruits and & getables & & & & & & & & \\
\hline Fresh fruit & Days & 0.75 & 1 & 0 & - & - & 33 & 51 & 16 \\
\hline
\end{tabular}

International Journal of Food Sciences and Nutrition Research 
Cheuk -A -Lam Gerani et al.

\begin{tabular}{|c|c|c|c|c|c|c|c|c|c|}
\hline & \multirow[t]{2}{*}{ p/week } & & 7 & 12 & & & & & \\
\hline & & & 5 & 4 & & & & & \\
\hline & \multirow{3}{*}{$\begin{array}{l}\text { Pieces } \\
\text { p/portion }\end{array}$} & \multirow[t]{3}{*}{$<0.01$} & 0 & 0 & \multirow[t]{3}{*}{19} & \multirow[t]{3}{*}{ - } & \multirow[t]{3}{*}{49} & \multirow[t]{3}{*}{45} & \multirow[t]{3}{*}{6} \\
\hline & & & 7 & 5 & & & & & \\
\hline & & & 3 & 2 & & & & & \\
\hline \multirow{3}{*}{$\begin{array}{l}\text { Fresh } \\
\text { vegetables }\end{array}$} & \multirow{3}{*}{$\begin{array}{l}\text { Days } \\
\text { p/week }\end{array}$} & \multirow[t]{3}{*}{$<0.01$} & 1 & 1 & \multirow[t]{3}{*}{-} & \multirow[t]{3}{*}{-} & \multirow[t]{3}{*}{28} & \multirow[t]{3}{*}{70} & \multirow[t]{3}{*}{2} \\
\hline & & & 7 & 7 & & & & & \\
\hline & & & 6 & 5 & & & & & \\
\hline $\begin{array}{l}\text { Serving } \\
\text { size } \\
\text { vegetables }\end{array}$ & $\begin{array}{l}\text { Plate } \\
\text { coverage } \\
\text { p/portion }\end{array}$ & & $1 / 3$ & $1 / 4$ & 4 & - & 24 & 75 & 1 \\
\hline \multirow{3}{*}{$\begin{array}{l}\text { Frozen } \\
\text { vegetables }\end{array}$} & \multirow{3}{*}{$\begin{array}{l}\text { Days } \\
\text { p/week }\end{array}$} & \multirow[t]{3}{*}{0.03} & 0 & 0 & \multirow[t]{3}{*}{78} & \multirow[t]{3}{*}{ - } & \multirow[t]{3}{*}{29} & \multirow[t]{3}{*}{67} & \multirow[t]{3}{*}{4} \\
\hline & & & 5 & 5 & & & & & \\
\hline & & & 2 & 1 & & & & & \\
\hline \multirow{3}{*}{$\begin{array}{l}\text { Canned } \\
\text { vegetables }\end{array}$} & \multirow{3}{*}{$\begin{array}{l}\text { Days } \\
\text { p/week }\end{array}$} & \multirow[t]{3}{*}{0.02} & 0 & 0 & \multirow[t]{3}{*}{61} & \multirow[t]{3}{*}{-} & \multirow[t]{3}{*}{26} & 69 & 5 \\
\hline & & & 7 & 7 & & & & & \\
\hline & & & 2 & 1 & & & & & \\
\hline Fish & & & & & & & & & \\
\hline Fresh fish & Days & $<0.01$ & 0 & 0 & 18 & - & 30 & 68 & 2 \\
\hline (general) & p/week & & 7 & 7 & & & & & \\
\hline & & & 2 & 2 & & & & & \\
\hline Fatty fish & Days & $<0.01$ & 0 & 0 & 70 & - & 36 & 62 & 2 \\
\hline & p/week & & 6 & 7 & & & & & \\
\hline & & & 2 & 1 & & & & & \\
\hline Lean fish & Days & $<0.01$ & 0 & 0 & 53 & - & 27 & 71 & 2 \\
\hline & $p /$ week & & 7 & 5 & & & & & \\
\hline & & & 2 & 1 & & & & & \\
\hline Canned fish & Days & $<0.01$ & 0 & 0 & 59 & & 49 & 47 & 3 \\
\hline & p/week & & 7 & 4 & & & & & \\
\hline & & & 2 & 1 & & & & & \\
\hline
\end{tabular}

\section{Starchy Carbohydrates: Bread, Rice, Potatoes}

The Wilcoxon-signed rank test proved that a significant part of bread consumers reduced the quantity of bread consumed during breakfast $(\mathrm{p}<0.01)$. However, the majority of respondents $(82 \%)$ reported no change in the type of bread consumed with more than half of the population consuming white bread (53\%). Moreover, despite the majority of households reporting no change in their frequency of rice consumption (i.e number of days $\mathrm{p} /$ week on which rice is consumed), another significant part had a lower post-devaluation intake ( $\mathrm{p}<0.01)$. These consumers shifted from two to one portion of rice per day. In addition, the amount of rice consumed per portion significantly changed as well $(\mathrm{p}<0.05)$, with a current mean consumption of 7 tablespoons per portion. There seemed to be a significant difference within $\mathrm{HH}$ income groups and the distribution of change in portion size $(\mathrm{p}<0.05)$.

The highest reductions were found in the lower income group. The difference in intake and proportion of households' consuming potatoes post-devaluation showed to be significantly lower than pre- devaluation $(\mathrm{p}<0.01)$. The majority consumers reduced their intake by one day per week and one potato potato per portion [17].

\section{Dairy}

Starting the onset of the devaluation, statistically significant reductions occurred in consumers' cheese, milk and yoghurt frequency consumption, with approximately 30 - $34 \%$ of households reducing their milk and cheese intake by one day $(\mathrm{p}<0.01)$. Furthermore, despite the fact that already less than half of the participants consumed yoghurt before the devaluation, there is still a significant reduction in yoghurt intake noticeable afterwards $(\mathrm{p}<0.01)$.

\section{White meat (poultry), eggs and meat substitutes}

Overall, $48 \%$ of households reported a reduction of meat in meat containing meals, of which $10 \%$ substituted the meat with either more vegetables $(8 \%)$ or roots and tubers $(2 \%)$. On the other hand, $17 \%$ of participants reported a reduction of expensive meats only, without substitutions of roots or tubers. The aforementioned is supported by the statistically signifcant reduction in the post-devaluation frequency consumption of fresh poultry $(\mathrm{p}<0.01)$ ), and that in portion sizes $(\mathrm{p}<0.01)$. The biggest group of portion 
size reducers decreased their intake with one piece of chicken [30].

The Wilcoxon signed-rank test showed that $20 \%$ of participants significantly decreased the frequency of chicken breast filet consumption after the devaluation $(\mathrm{p}<0.01)$. The Wilcoxon signed-rank test also stated a significant difference in the proportion of households' pre-and post-devaluation egg consumption $(\mathrm{p}<0.01)$; nearly $21 \%$ of the respondents reduced their egg consumption with one day per week.

\section{Fruits}

The frequency in post-devaluation consumption of fresh fruits did not significantly differ from the pre-devaluation frequency $(p>0.05)$. However, almost half of fruit consumers reported a decrease in the fresh fruit servings, reducing their intake from three to two pieces per portion after the devaluation $(\mathrm{p}<0.01)$. The majority of respondents (41\%) still consume the same type of fruit as prior to the devaluation, whereas $38 \%$ switched to cheaper fruits such as banana (31\%), mango and papaya (7\%).

\section{Vegetables}

For all vegetables the post-devaluation frequency consumption scores were significantly one day lower than the pre-devaluation consumption scores $(\mathrm{p}<0.05)$. Not only the frequency, but also the portion sizes declined $(\mathrm{p}<0.01)$. Overall, $25 \%$ of the participants reduced their portion size from $1 / 4$ to $1 / 3$ of plate coverage. Also $20 \%$ reported a switch to cheaper vegetables since the commencement of the devaluation. Moreover, those with lowest economic means had a greater post-devaluation reduction of fresh and canned vegetables, compared to middle-
- and high-income earners $[5,18]$.

\section{Fish}

In general, significant reductions in overall fish consumption occurred with explicit reductions in fatty, lean and canned fish intake ( $p$ <0.01). Median frequency consumption scores shifted from 2 days to 1 day per week post-devaluation. Despite the significant reductions in frequency consumption, the majority of participants still consume the same type of fatty (19\%) and lean fish $(30 \%)$. In contrast, $22 \%$ of participants reported a shift to consumption of cheaper fresh fish (parts). Further, interesting shifts in terms of portion size were observed: $28 \%$ of participants reduced their serving size from $1 / 2$ to $1 / 3$ of plate coverages (7\%), $1 / 2$ to $1 / 4$ plate coverage (9\%) and $1 / 3$ to $1 / 4(12 \%)$ of plate coverage [21].

\section{Findings on changes in Low-Quality Diets}

Table 2 presents significant pre- and post-devaluation differences in food groups essentially belonging to a low-quality diet. Moreover, it lists the minimum, maximum and median consumption measurements pre-and post the currency devaluation. In addition, the proportion of households reducing, maintaining or increasing their intake is given.

Table 2: Comparative analyses of median reported pre-and post-devaluation food intake and consumer change concerning low quality diets in Suriname, 2015-2016.

\begin{tabular}{|c|c|c|c|c|c|c|c|c|c|}
\hline \multirow[t]{6}{*}{ Food group } & \multirow{6}{*}{$\begin{array}{l}\text { Reporting } \\
\text { unit }\end{array}$} & \multirow{6}{*}{$\begin{array}{l}\text { Sig } \\
\text { value } \\
\text { (p) }{ }^{4}\end{array}$} & \multirow{2}{*}{\multicolumn{2}{|c|}{$\begin{array}{l}\text { Min. } \\
\text { Max. }\end{array}$}} & \multirow{6}{*}{$\begin{array}{l}\text { Non - } \\
\text { consumer } \\
(\%)\end{array}$} & \multirow{2}{*}{\multicolumn{4}{|c|}{$\begin{array}{l}\text { Consumer change in food } \\
\text { intake since the devaluation }\end{array}$}} \\
\hline & & & & & & & & & \\
\hline & & & \multicolumn{2}{|l|}{ Median } & & & \multirow{4}{*}{$\begin{array}{l}\text { Lower } \\
(\%)\end{array}$} & \multirow{4}{*}{$\begin{array}{l}\text { Same } \\
(\%)\end{array}$} & \\
\hline & & & Before & After & & \multirow{3}{*}{$\begin{array}{l}\text { Stopped } \\
(\%)\end{array}$} & & & \multirow[t]{3}{*}{ Higher } \\
\hline & & & 5 & 3 & & & & & \\
\hline & & & 2 & 0 & & & & & \\
\hline \multicolumn{10}{|l|}{ Junk food } \\
\hline \multirow{5}{*}{$\begin{array}{l}\text { Frequency } \\
\text { visiting Junk } \\
\text { Food places }\end{array}$} & \multirow{5}{*}{$\begin{array}{l}\text { Days } \\
\text { p/month }\end{array}$} & \multirow[t]{5}{*}{$<0.01$} & 0 & 0 & \multirow[t]{5}{*}{51} & \multirow[t]{5}{*}{44} & \multirow[t]{5}{*}{-} & \multirow[t]{5}{*}{56} & \multirow[t]{5}{*}{-} \\
\hline & & & 20 & 20 & & & & & \\
\hline & & & 2 & 1 & & & & & \\
\hline & & & 8 & 6 & & & & & \\
\hline & & & 3 & 1 & & & & & \\
\hline \multirow[t]{4}{*}{ Potato fries } & \multirow{3}{*}{$\begin{array}{l}\text { Days } \\
\text { p/week }\end{array}$} & \multirow[t]{3}{*}{$<0.01$} & 0 & 0 & \multirow[t]{3}{*}{51} & \multirow[t]{3}{*}{-} & \multirow[t]{3}{*}{35} & \multirow[t]{3}{*}{64} & \multirow[t]{3}{*}{1} \\
\hline & & & 10 & 6 & & & & & \\
\hline & & & 2 & 1 & & & & & \\
\hline & $\begin{array}{l}\text { Small, } \\
\text { Medium, } \\
\text { Large }\end{array}$ & $<0.01$ & Medium & Small & 43 & - & 28 & 71 & 1 \\
\hline
\end{tabular}


Cheuk -A -Lam Gerani et al.

\begin{tabular}{|c|c|c|c|c|c|c|c|c|c|}
\hline \multirow[t]{3}{*}{ Hamburgers } & \multirow{3}{*}{$\begin{array}{l}\text { Days } \\
\text { p/month }\end{array}$} & \multirow[t]{3}{*}{$<0.01$} & 0 & 0 & \multirow[t]{3}{*}{78} & \multirow[t]{3}{*}{-} & \multirow[t]{3}{*}{44} & \multirow[t]{3}{*}{56} & \multirow[t]{3}{*}{ - } \\
\hline & & & 12 & 8 & & & & & \\
\hline & & & 4 & 1 & & & & & \\
\hline \multirow{4}{*}{$\begin{array}{l}\text { Size of } \\
\text { hamburger }\end{array}$} & \multirow{3}{*}{$\begin{array}{l}\text { Quantity } \\
\text { p/portion }\end{array}$} & \multirow[t]{3}{*}{$<0.01$} & 1 & 0 & \multirow[t]{3}{*}{76} & \multirow[t]{3}{*}{-} & \multirow[t]{3}{*}{29} & \multirow[t]{3}{*}{7} & \multirow[t]{3}{*}{ - } \\
\hline & & & 8 & 4 & & & & & \\
\hline & & & 1 & 1 & & & & & \\
\hline & $S, M, L$ & $<0.01$ & Medium & Medium & 71 & & 25 & 75 & \\
\hline \multirow[t]{3}{*}{ Pizza } & \multirow{3}{*}{$\begin{array}{l}\text { Days } \\
\text { p/month }\end{array}$} & \multirow[t]{3}{*}{$<0.01$} & 0 & 0 & \multirow[t]{3}{*}{68} & \multirow[t]{3}{*}{-} & \multirow[t]{3}{*}{31} & \multirow[t]{3}{*}{69} & \multirow[t]{3}{*}{ - } \\
\hline & & & 4 & 4 & & & & & \\
\hline & & & 1 & 1 & & & & & \\
\hline Sugar sweete & led bevera & non-alc & holic & & & & & & \\
\hline Soft drinks & Days & $<0.01$ & 0 & 0 & 29 & - & 42 & 57 & 1 \\
\hline & $p /$ week & & 4 & 4 & & & & & \\
\hline & & & 4 & 2 & & & & & \\
\hline & Glasses & $<0.01$ & 0 & 0 & 28 & - & 34 & 64 & 2 \\
\hline & p/day & & 10 & 10 & & & & & \\
\hline & & & 2 & 1 & & & & & \\
\hline Juice & Days & $<0.01$ & 1 & 0 & 47 & - & 27 & 72 & 1 \\
\hline (concentrate) & $p /$ week & & 3 & 3 & & & & & \\
\hline & & & 4 & 2 & & & & & \\
\hline & Glasses & $<0.01$ & 1 & 0 & 30 & - & 29 & 70 & 1 \\
\hline & p/day & & 8 & 7 & & & & & \\
\hline & & & 2 & 1 & & & & & \\
\hline & & & 14 & 7 & & & & & \\
\hline & & & 5 & 5 & & & & & \\
\hline Discretionar & foods & & & & & & & & \\
\hline Frequency & Times & $<0.01$ & 0 & 0 & 61 & - & 43 & 54 & 3 \\
\hline baked & p/day & & 6 & 4 & & & & & \\
\hline $\begin{array}{l}\text { goods, } \\
\text { pastries } \\
\text { (sweet } \\
\text { desert) }\end{array}$ & & & 1 & 1 & & & & & \\
\hline Chips & Times & $<0.01$ & 0 & 0 & 48 & - & 40 & 58 & 2 \\
\hline & $p / d a y$ & & 7 & 5 & & & & & \\
\hline & & & 1 & 1 & & & & & \\
\hline Cookies & Times & $<0.01$ & 0 & 0 & 65 & - & 37 & 62 & 1 \\
\hline & $p / d a y$ & & 7 & 7 & & & & & \\
\hline & & & 1 & 1 & & & & & \\
\hline Chocolate & Times & $<0.01$ & 0 & 0 & 74 & - & 46 & 52 & 2 \\
\hline & p/day & & 5 & 4 & & & & & \\
\hline & & & 1 & 0 & & & & & \\
\hline Ice-cream & Scoops & $<0.01$ & 1 & 0 & 58 & - & 37 & 62 & 1 \\
\hline & $p /$ serving & & 5 & 5 & & & & & \\
\hline & & & 2 & 2 & & & & & \\
\hline
\end{tabular}

\section{Junk food}

Table 2 shows that $44 \%$ of consumers stopped visiting junk food restaurants $(\mathrm{p}<0.01)$. Observing the different dishes sold within fast food restaurants, we see that the post devaluation frequency and portion size of fries, burgers and pizza significantly declined compared to before the devaluation $(\mathrm{p}<0.01)$. The vast majority of fries' consumers (59\%), shifted from medium sized to small fries portion post-devaluation. Moreover, despite the lower number of respondents, lower income (Srd 800 - 1500) and less educated households have been found to reduce their portion sizes much more compared to their larger competitors $(\mathrm{p}<0.05)$.

\section{Non-alcoholic sugar-sweetened beverages}

The Wilcoxon signed-rank test showed that the devaluation elicited a statistically significant change in the frequency and the daily amount per serving, in which carbonated beverages and juices are consumed 
( $\mathrm{p}<0.01$ ). For both, the median frequency score pre-was significantly higher than post-devaluation score. When it comes to the amount consumed, approximately $30 \%$ of SSB consumers had a lower intake after compared to before the devaluation (table 4), with a mean reduction of $33 \%$. However, between 60 and $70 \%$ of respondents maintained their SSB intake, of which $11 \%$ switched to cheaper brands in order to maintain the same frequency of consumption.

\section{Discretionary Foods}

For all discretionary foods under analyses we observed a significant change in consumption $(\mathrm{p}<0.01)$ with around $40 \%$ of consumers reducing their snack consumption. The median intake for all snack types was equal to one time per day $[14,19,22]$.

\section{Discussion \& Conclusions}

The fall of the Surinamese currency, in combination with country's dependency on imported foods, led to higher national food prices. Starting the onset off the currency devaluation, we witnessed changing consumption patterns and coping strategies in terms of reduced number of meals, reduced portion sizes, and shifts towards more affordable foods (fig.1). The adopted coping strategies, mostly noticeable within lower-income households, were similar to those in Africa and Asia. For example, in the face of higher rice prices households tried to cope by reducing their overall cereal \& grain intake [20,26,39,49]. Higher cereal prices might reduce the intake of non-staples as less budget is available for the latter's purchase. The aforementioned being confirmed by the fact that, post the currency devaluation in Suriname, an apparent lower reduction in rice intake was observed compared to e.g. reductions in meat, fruits and fish consumption (regardless of the immense increase in the price of rice). It is important to highlight the significant impact of transitioning diets due to higher food prices with respect to potential implications for health.

Significant proportions of Surinamese households possess an increased risk of poor diet quality through reduced intakes of high-quality foods such as fruits, vegetables, lean meat and fatty fish. This reduces the protective health benefits of high-quality foods towards the incidence of NCDs, and increases the risk of micro- and macronutrient deficiencies, especially among populations that are already subject to food/nutrition insecurity [35]. As an example, we witnessed reductions in intake of animal source foods and small substitutions with either more vegetables or roots and tubers. Another part of the population had especially reduced the more expensive, yet leanest, meat types (i.e. chicken breast filet) without substitution. This strategy of reducing animal source foods (without substitution) has a high potential of reducing population's protein intake and inducing protein foods (without substitution) has a high potential of malnutrition.
Furthermore, consumption of cheaper, yet fatty meats, in combination with low fibre intake as a result of decreased fruit and vegetable and low whole grains consumption, increases the risk of coronary heart diseases, diabetes mellitus type 2 and colorectal cancer $[2,3,8,11,29,31,34,41,47]$.

With cardiovascular diseases and diabetes already being major public health concerns in Suriname, we must be alert that lowering intakes of vegetables will negatively influence any remediation plan against these public health burdens.

However, there have been several potential positive changes as well, with households significantly reducing the intake of junk food, snacks and sugarsweetened beverages. As these contribute to the intake of high-calories and possess low nutritional value, lowering their consumption might have a beneficial health impact on population groups already coping with overweight and related non-communicable diseases such as cardiovascular diseases, hypertension and diabetes [44]. Irrespective of compensatory purchasing falling beyond the scope of this study, we still witnessed a switch to cheaper brands of soft drinks and juices in order to maintain the same consumption level. Even so, with the majority of consumers reporting a once-a-day SSB consumption, we must be mindful of chances of underreporting. This study was the first in Suriname, assessing the impact of higher food prices on food intake. With existing literature mainly highlighting the impact of higher food prices on lower-income households, this study brought forward results showing the impact of an economic crisis likewise affecting middle- and higher income households' food expenditures [51]. However, the greater sensitivity of low-income groups to food price changes suggests that targeted food groups could alter the diets and nutritional health of these priority populations through stabilization of food prices or subsidization of high-quality foods. As such, it is of eminent importance to ensure food security through the driver of food consumption and independence from international food commodities, thereby turning the vicious cycle hampering the agricultural sector of reaching its full potential into a virtuous one $[23,37,46]$. Proper development of the agricultural sector, and therefore the rural population, can help stabilize national food prices, positively affecting population nutrition and health status. This requires political, public and private commitment. 
This study sets the context for more comprehensive and largerscale food consumption research in Suriname, and offers the opportunity to use the evidence gathered as step-stone, to better understand the source of our public health issues in order to initiate effective nutrition intervention planning $[6,9,16,42,50]$.

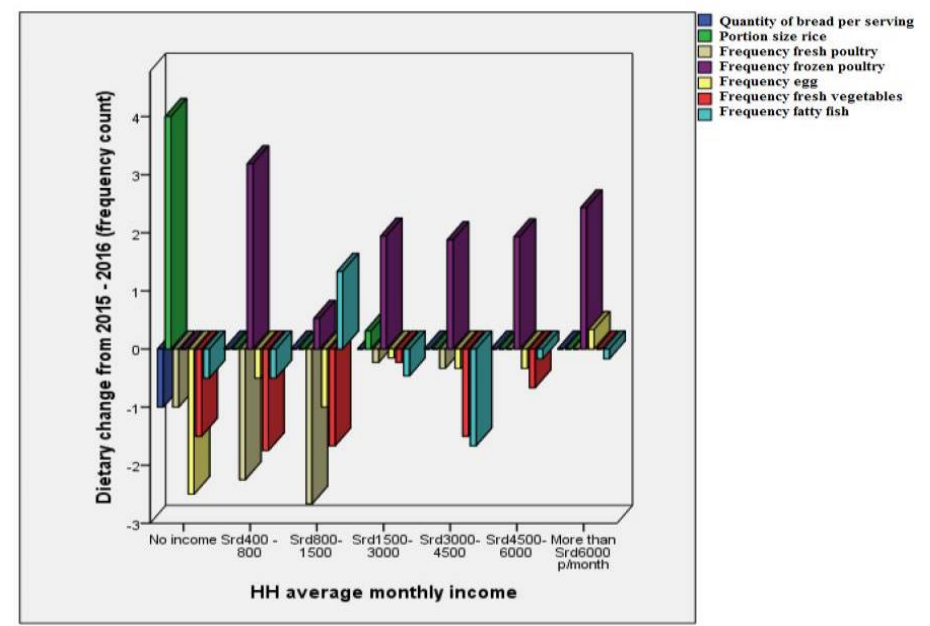

Figure 1: Transitions in high-quality food groups based on household income indicated pre- and post the currency devaluation in Suriname, 2015-2016.

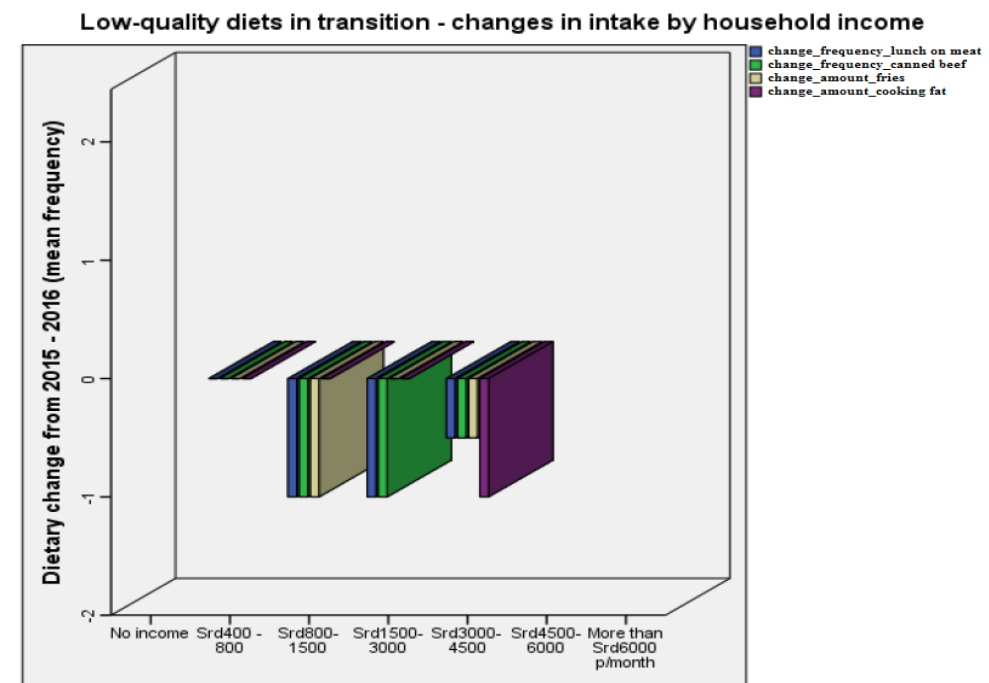

Figure 2: Transitions in low-quality food groups based on household income indicated pre- and post the currency devaluation in Suriname, 2015-2016.

\section{Acknowledgement}

Express my sincere gratitude to my promotors Prof. dr.Ir. John van Camp, Prof. dr. Ir. Marijke D'Haese, and Prof. Carl Lachat who have kindly guided and encouraged me from the beginning. Also a special thanks to the tutors at the Ministry of Health in Suriname: Mr. Adley Breeveld, and Mrs. Deborah Stijnberg, and the survey assistants whom made it possible to successfully conduct the data collection in my home country. Additionally, I would like to acknowledge Erasmus Mundus Consortium II-
-CARIBU, especially Mrs. Marie Aurousseau and Charlotte Moulin, for their generous support, and the opportunity to make my dream of studying abroad come true.

\section{Ethics}

This project is approved from UZ Medical Committee Ghent.

\section{Conflict of Interest}

The authors have no conflicts of interest to declare.

\section{References}

1. Andrieu E, Darmon N, Drewnowski A. Low-cost diets: more energy, fewer nutrients. Eur J Clin Nutr. 2006 Mar; 60:434-436.

2. Aune D, Norat T, Romundstad P, Vatten LJ. Whole grain and refined grain consumption and the risk of type 2 diabetes: a systematic review and dose-response meta-analysis of cohort studies. Eur J Epidemiol. 2013; 28:845-858.

3. Aune D, Ursin G, Veierod MB. Meat consumption and the risk of type 2 diabetes: a systematic review and meta-analysis of cohort studies. Diabetologia. 2009; 52:2277-2287

4. Becerra L, Cheuk-A-Lam G, Kaki K, Muyama L. A Report on Food and Nutrition Security in Mexico, Germany, Uganda, Suriname, Ghana and Bangladesh. 2015.

5. Bloem MW, De Pee S, Darnton-Hill I. Micronutrient Deficiencies and Maternal Thinness. In Preventive Nutrition. Totowa, NJ: Humana Press. 2005; 689-710

6. Bloom, DE, Canning, D, Sevilla J. The Effect of Health on Economic Growth: A Production Function Approach. World Development. 2004; 32:1-13.

7. Brinkman HJ, de Pee S, Sanogo I, et al. High food prices and the global financial crisis have reduced access to nutritious food and worsened nutritional status and health. J Nutr. $2010 ; 140: 153 S-161 S$

8. Carter P, Gray LJ, Troughton J, et al. Fruit and vegetable intake and incidence of type 2 diabetes mellitus: systematic review and meta-analysis. BMJ. 2010;341:c4229.

9. Christian, P. Impact of the economic crisis and increase in food prices on child mortality: exploring nutritional pathways. J Nutr. 2010; 140:177S-181S. 
10. Cornelsen L, Green R, Turner R, et al. What Happens to Patterns of Food Consumption when Food Prices Change? Evidence from A Systematic Review and Meta-Analysis of Food Price Elasticities Globally. Health Econ. 2015;24:1548-1559.

11. Darmon N, Drewnowski A. Contribution of food prices and diet cost to socioeconomic disparities in diet quality and health: a systematic review and analysis. Nutr Rev. 2015; 73:643-660.

12. Szwarcwald CL, Malta DC, Lima MG, et al . Social inequalities in health behaviors among Brazilian adults: National Health Survey, 2013. Int J Equity Health. 2016; 15:148.

13. Dibsdall LA, Lambert N, Bobbin RF, Frewer LJ. Lowincome consumers' attitudes and behaviour towards access, availability and motivation to eat fruit and vegetables. Public Health Nutr. 2003; 6:159-168.

14. Drewnowski A, Darmon N. The economics of obesity: dietary energy density and energy cost. Am J Clin Nutr. 2005; 82(1 Suppl):265S-273S.

15. Esmaeili A, Shokoohi Z. Assessing the effect of oil price on world food prices: Application of principal component analysis. Energy Policy. 2011; 39:1022-1025S

16. Eyles H, Ni Mhurchu C, Nghiem N, Blakely T. Food pricing strategies, population diets, and non-communicable disease: a systematic review of simulation studies. PLoS Med. 2012; 9:e1001353.

17. FAO 2017. Human nutrition in the developing world-Part III. Disorders of malnutrition. June 2, 2017.

18. Green R, Cornelsen L, Dangour AD, et al. The effect of rising food prices on food consumption: systematic review with meta-regression. BMJ. 2013; 346:f3703.

19. Han E, Powell LM. Effect of food prices on the prevalence of obesity among young adults. Public Health. 2011; 125:129-135.

20. Samuel Hauenstein S, Sierd H, Bernardette C. Field analysis oF volatile global Food commodity prices, Food security and child malnutrition Feeding hunger and insecurity. Paris: Action Against Hunger. 2009.

21. Hooper L, Thompson RL, Harrison RA, et al. Risks and benefits of omega 3 fats for mortality, cardiovascular disease, and cancer: systematic review. BMJ. 2006; 332:752760.

22. Hulshof KF, Brussaard JH, Kruizinga AG, et al. Socioeconomic status, dietary intake and 10 y trends: the Dutch National Food Consumption Survey. Eur J Clin Nutr. 2003; 57:128-137.

23. IFPRI : International Food Policy Research Institute. Food Security. May, 2017.

24. IMF. International Monetary Fund Data - Access to Macroeconomic \&amp; financial data. May, 2017.
25. Jones, NRV, Conklin, AI, Suhrcke M, Monsivais P. The Growing Price Gap between More and Less Healthy Foods: Analysis of a Novel Longitudinal UK Dataset. PLoS One. 2014; 9:e109343.

26. Ledikwe JH, Blanck HM, Khan LK, et al. Lowenergy-density diets are associated with high diet quality in adults in the United States. J Am Diet Assoc. 2006; 106:1172-1180.

27. Mayén AL, Marques-Vidal P, Paccaud F, et al. Socioeconomic determinants of dietary patterns in low- and middle-income countries: a systematic review. Am J Clin Nutr. 2014; 100:1520-1531.

28. Mendoza Armando, Machado Roberto. The escalation in world food prices and its implications for the Caribbean. Caribbean Development Report. 2008.

29. Mente A, de Koning L, Shannon HS, Anand SS. A Systematic Review of the Evidence Supporting a Causal Link Between Dietary Factors and Coronary Heart Disease. Arch Intern Med. 2009; 169:659-669.

30. Micha R, Michas G, Mozaffarian D. Unprocessed red and processed meats and risk of coronary artery disease and type 2 diabetes--an updated review of the evidence. Curr Atheroscler Rep. $2012 ; 14: 515-524$.

31. Micha R, Wallace SK, Mozaffarian D. Red and Processed Meat Consumption and Risk of Incident Coronary Heart Disease, Stroke, and Diabetes Mellitus. A Systematic Review and MetaAnalysis. Circulation. 2010; 121:2271-2283.

32. Mitchell, D. A Note on Rising Food Prices. Retrieved from World Bank Policy Research Working.2008; 4682.

33. Mizdrak A, Scarborough P, Waterlander WE, Rayner M. Differential Responses to Food Price Changes by Personal Characteristic: A Systematic Review of Experimental Studies. PLoS One. 2015; 10:e0130320.

34. Murayama, N. Effects of Socioeconomic Status on Nutrition in Asia and Future Nutrition Policy Studies. J Nutr Sci Vitaminol (Tokyo). 2015; 61Suppl:S66-S68.

35. Nandy S, Daoud A, Gordon D. Examining the changing profile of undernutrition in the context of food price rises and greater inequality. Soc Sci Med. 2016; 149:153-163.

36. Pechey R, Monsivais P. Socioeconomic inequalities in the healthiness of food choices: Exploring the contributions of food expenditures. Prev Med. 2016; 88:203-209. 
37. Melissa NP, Philip RM, Megan LC, Roni AN. A systematic review of urban agriculture and food security impacts in lowincome countries. Food Policy. 2015; 55:131-146.

38. Rao M, Afshin A, Singh G, Mozaffarian D. Do healthier foods and diet patterns cost more than less healthy options? A systematic review and meta-analysis. BMJ Open. 2013; 3:e004277.

39. Ruel MT, Garrett JL, Hawkes C, Cohen MJ. The Food, Fuel, and Financial Crises Affect the Urban and Rural Poor Disproportionately: A Review of the Evidence. J Nutr. 2010 Jan;140(1):170S-6S.

40. Schroeter C, Lusk J, Tyner W. Determining the impact of food price and income changes on body weight. J Health Econ. 2008; 27:45-68.

41. Schwingshackl L, Schwedhelm C, Hoffmann G, et al. Food groups and risk of all-cause mortality: a systematic review and meta-analysis of prospective studies. Am J Clin Nutr. 2017; 105:1462-1473.

42. Simou E, Koutsogeorgou E. Effects of the economic crisis on health and healthcare in Greece in the literature from 2009 to 2013: a systematic review. Health Policy. 2014; 115:111-119.

43. Singh GM, Micha R, Khatibzadeh S, et al. Global, regional, and national consumption of sugar-sweetened beverages, fruit juices, and milk: a systematic assessment of beverage intake in 187 countries. PLoS One. 2015; 10:e0124845.

44. Suriname Ministry of Health. National Action Plan for the Prevention and Control of Non-Communicable Diseases 2015-2020. 2015.

45. The World Food Program. World Hunger Series: Hunger and Markets. 2009; 139-140.

46. United Nations. Hunger and food security - United Nations Sustainable Development. 2015.

47. Sukumar V, Jasmine F, Sanjay B, et al. Food Price Spikes Are Associated with Increased Malnutrition among Children in Andhra Pradesh, India. J Nutr. 2015; 145:1942-1949.

48. Webb, P. Medium- to Long-Run Implications of High Food Prices for Global Nutrition. J Nutr. 2010; 140:143S-147S.

49. WHO. Nutrition Landscape Information System: Nutrition Landscape Information System (NLIS) Country Profile. 2011.

50. WHO. Healthy Cities Pécs Declaration. 2017.

51. Waters H, Saadah F, Pradhan M. The impact of the 1997-98 East Asian economic crisis on health and health care in Indonesia. Health Policy Plan. 2003; 18:172-181.

52. Epstein LH, Jankowiak N, Nederkoorn C, et al. Experimental research on the relation between food price changes and food-purchasing patterns: a targeted review. Am J Clin Nutr. 2012; 95: 789-809.
53. Carlson A, Frazao E. Food costs, diet quality and energy balance in the United States. Physiol Behav. 2014; 134:20-31. 